and had to be returned. Enquiries were made, the whole matter was discussed over again and it was finally decided that the Royal Navy should go over to $360^{\circ}$ cards.

I have seen a French naval card from before 1870 which has a $360^{\circ}$ graduation, but I believe this to be a rare specimen. The light type dry cards which they were using at the turn of the century had the $90^{\circ}$ graduation and I imagine that they changed to $360^{\circ}$ when they adopted liquid compasses shortly before World War I, the Italian Navy doing the same.

The United States Navy was still using $90^{\circ}$ cards about i 880 and probably changed to $360^{\circ}$ about 1900 , as did the Germany Navy.

One of the most conservative bodies of seamen were British fishermen, who were still often to be found between the wars using cards marked in points without any degrees.

\title{
Radar and the Rule of the Road
}

\section{Captain W. Burger and Captain A. G. Corbet}

THE following amendments and additions to the existing (1960) Regulations for Preventing Collisions at Sea are offered for comment by Institute members and others interested in this problem.

The only comment which we wish to make about them at this time is that we do not claim that any of the ideas on which these suggested new rules are based are our original ideas-they have only been sorted out, into what we hope will prove to be a satisfactory arrangement, from many ideas which have come to light and have been aired during exercises and discussions that have taken place during radar simulator courses conducted at the Welsh College of Advanced Technology over the last five years and during discussions with many members of the staffs of other nautical colleges and with nautical surveyors of the Board of Trade. The ideas put forward by many notable persons in the various nautical publications have also been studied and have greatly influenced us.

The reason why we do not wish to comment on the suggested rules further than this at this stage is because we are hoping, perhaps rather wishfully, that they have no real weaknesses, are completely self-explanatory and thus do not really require pages and pages of interpretation and expansion to make them clear. Wishful indeed!

Rule 16

(a) Unchanged.

(b) A power-driven vessel hearing, apparently forward of her beam, the fog signal of a vessel, the position of which is not fully ascertained by sighting, shall, so far as the circumstances of the case admit, stop her engines and navigate with particular caution until danger of collision is over.

(c) (i) A power-driven vessel which detects, by radar, the presence of another 
vessel, which is neither in sight nor heard, right ahead and on a steady bearing, shall, if the range of the vessel is decreasing at a speed faster than the speed of the power-driven vessel and if the circumstances of the case admit, alter course to starboard to put the other vessel on the port side or right astern. The powerdriven vessel should then continue to navigate with particular caution until danger of collision is over.

(ii) A power-driven vessel which detects, by radar, the presence of another vessel, which is neither in sight or heard, right ahead and on a steady bearing, shall, if the range of the vessel is decreasing at a speed slower than the speed of the power-driven vessel and if the circumstances of the case admit, reduce speed or stop or alter course to starboard or reduce speed and alter course to starboard. The power-driven vessel should then continue to navigate with particular caution until danger of collision is over.

(iii) A power-driven vessel which detects, by radar, the presence of another vessel, which is not in sight, right astern and on a steady bearing, shall, if there is risk of collision with this vessel and if the circumstances of the case admit, alter course to port or increase speed or alter course to port and increase speed. The power-driven vessel should then continue to navigate with particular caution until danger of collision is over.

(iv) A power-driven vessel which detects, by radar, the presence of another vessel, which is neither in sight nor heard, on the starboard side, shall, if there is a risk of a close quarters situation with this vessel and if the circumstances of the case admit, alter course to put the other vessel on the port side or right astern. The power-driven vessel should then continue to navigate with particular caution, varying her speed if necessary, until danger of collision is over.

(v) A power-driven vessel which detects, by radar, the presence of another vessel, which is neither in sight nor heard, on the port side, may, if there is risk of a close quarters situation with this vessel and if the circumstances of the case admit, alter course but she shall keep the other vessel on the port side or put her right astern. The power-driven vessel should then continue to navigate with particular caution, varying her speed if necessary, until danger of collision is over.

(vi) A power-driven vessel which detects the presence of other vessels forward of her beam before hearing their fog signals or sighting them visually, may take early and substantial action to avoid a close quarters situation but, if this cannot be avoided, she shall, so far as the circumstances of the case admit, stop her engines in proper time to avoid collision and then continue to navigate with particular caution until danger of collision is over.

(vii) Any vessel, other than a power-driven vessel, which detects, by radar, the presence of another vessel, which is not in sight, should, if there is a risk of a close quarters situation and if practicable, navigate in accordance with the directions given for a power-driven vessel in subsections (i), (ii), (iii), (iv), (v) and (vi) of this section, so far as she is able within the limits of her design, class, occupation and condition or otherwise she shall take such other action within her capabilities, as will best aid to avert collision.

Amendments and Additions to the Annex.

Delete section (6).

Section (8). Insert: 'forward of the beam' after 'close quarters situation'. 